\title{
FISHERIES ASSOCIATED WITH MANGROVE ECOSYSTEM IN INDONESIA: A View from a Mangrove Ecologist
}

\author{
SUKRISTIJONO SUKARDJO \\ The Centre for Oceanological Research and Development, Indonesian Institute of Sciences, \\ Jl.Pasir Putih 1 Ancol Timur, P.O.Box 4801 JKTF Jakarta 11048, Indonesia. E-mail: \\ s_sukardjo@telkom.net and s_sukardjo@yahoo.com
}

\begin{abstract}
Blessed with mangrove area of some 9.6 million ha in extent, Indonesia represents an important country with fishery resources being a source of food and nutrients. The fishery resources utilized by man, such as fishes, crustaceans and mollusks that are found in the mangrove ecosystem/swamp area arc enormous. There is a range of species caught in the mangrove and surrounding areas with over 70 species. However, commercially valued species are limited to a few such as rabbit fish, snapper, grouper, marline catfish, fringe-scale sardine, and anchovy. Leaf detritus from mangroves contribute a major energy input into fisheries. But information about the study on the relationship between fishery species and mangroves, ecologically and biologically, arc scanty. The mangrove is a physiographic unit, the principal components of which arc organisms. Therefore, the problems are predominantly of a biological nature (e.g., mangroves - fishery relationship). Positive correlation between the mangrove area and penaeid shrimp catch found in Indonesia, the Philippines, Australia and Mexico. Finally, the most important part of the variance of the MSY (Maximum Sustainable Yield) of penaieds (53\% of the variance) could be explained by a combination of area of mangrove habitats and latitude.
\end{abstract}

Keywords : Indonesia/Mangrove/Ecosystem/Fisheries/Ecology/Coastal areas/Fishes/Molluscans/ Crustaceans.

\section{INTRODUCTION}

Indonesia $\left(6^{\circ} \mathrm{N}-10^{\circ} \mathrm{S}\right.$ and $\left.95^{\circ} \mathrm{E}-142^{\circ} \mathrm{E}\right)$ is an archipelagic state in the tropical area with 18,110 islands and almost more than 108,000 km of coastlines (Sukardjo 1997; Anonim 2003). These areas form an important and valuable natural resource with potential economic value, and a potentially important production area for food. People have long relied on coastal waters as a source of food. The coastal zone of the Indonesian waters includes a number of bays and gulfs into which large and small rivers empty, creating estuarine conditions in the inshore areas. The extent of the estuarine zone in the sea varies according to the size of the river and the volume of its freshwater discharge, the steepness of the gradient, and the tidal range. Also, these coastal zones contain diverse productive ecosystems that include mangroves, sand beaches, several riverbasins and freshwater bodies. Each of these ecosystems has components that are exploited in a wide variety and used with different intensities because of socio-economic and socio-cultural demands. Therefore, Indonesia, is considered as one of the largest maritime country in the world. 
With almost more than $75 \%$ of Indonesian territories being seas, marine fishery is one of the important renewable resources for the nation. For instance, 1,450,000 tons of pelagic fish had been caught for whole Indonesia (EPS 1995). Ironically, depletion of the marine resources is starting to become evident in Indonesia. The fishery resources utilized by man, such as fishes, crustaceans and mollusks (oyster, mussel, cockle), that are found in the mangrove swamp area are enormous. Indigenous people in Indonesia have exploited the biota of mangrove waters for centuries, and fish and shrimp are still one of the major products harvested from this mangrove swamp (Schuster 1952). Thus, aquatic resources play a vital role in the social, economic and ecological well-being of coastal communities in Indonesia. Furthermore, the value of the mangrove ecosystems is not just of academic interest, it also relates to their cultural and commercial value. The full economic value should be determined in order to make intelligent decisions about their future use. Thus the understanding of both the roles and the functions of mangrove ecosystem in terms of fishery in Indonesia is also of considerable importance. The following paper is, therefore, an effort to review and methodize existing information on the mangrove-fishery association subject in Indonesia.

\section{THE INDONESIAN MANGROVES: A Fishery Feature}

Situated at the two continents, Asia and Australia, and two oceans, Pacific and Indian, the Indonesia archipelago, has an ecologically and economically strategic position with distinct culture that took shape on these 18,110 islands. The climate of Indonesia is tropical and generally governed by the monsoonal situation, resulting in fairly regular climate variations. During the winter, the northern part of the earth has air pressure around Asia higher than that of Australia. North of the equator, the wind blows from North and East - the NE monsoon, at and near the equator, it becomes more North and North - NW monsoon. South of the equator the winds turns from NW via W to SW - the West monsoon. Consequently, Indonesia is blessed with high annual rainfall $(>1500 \mathrm{~mm} /$ year) and comfortable tropical temperatures. Moreover, Indonesia's waters are homogeneous to an unusual degree. The country lies entirely within the tropics, straddling the equator from roughly $5^{\circ} \mathrm{N}$ to $10^{\circ} \mathrm{S}$ latitude. Oceanographic conditions are uniform in this equatorial zone, characterized by lack of seasonal changes and consistently warm waters. The Indonesian waters are ideal monsoon region. These are very favorable for mangroves development. Consequently, large areas of the mangrove ecosystem in Indonesia are to be found and estimated at about the range of 4.25 million ha (1982) to 9.6 million ha (2002). Therefore, mangrove forests are a major feature of the coastline in many islands of Indonesia. However, this figure and its distributional extent is still in debates for further clarifications. This type of forest vegetation is common in the Malesia (comprising the political states of Indonesia, Malaysia, Singapore, Brunei Darussalam, the Philippines and PNG) and has stimulated the interest of various systematics and ecologists as can be learned from comprehensive 
studies by Watson (1928) in Malay Peninsula, and by Brown and Fisher (1918) in the Philippines, and by Becking et al. (1922) in Indonesia. A substantial body of information exists on the biology, ecology and other aspects of mangroves or mangrove ecosystem or mangrove forests or mangals (Macnae 1968). The bibliography lists of mangrove forests in Indonesia can be found in e.g., Rollets (1997). However, recent records of mangrove literatures can be learned through a series of the Proceedings of the National Seminar on Mangrove Ecosystem (I-VI) and others. But our knowledge of the mangrove fish fauna in contrast, is limited to a handful of papers that deal with inventory. A similar state of knowledge exists on the association between mangroves and fisheries (See: Macnae 1974 for general information); and the economic value of the fisheries function of mangroves in the Bintuni Bay, Irian Jaya, has been discussed by Ruitenbeek (1991). Commercial fisheries in Indonesia or Indonesia's artisanal commercial fisheries are largely dependent upon coastal and estuarine fishes.

In Indonesia, mangrove forests reach their greater structural and floristic diversity in all biggest islands e.g., Sumatra, Kalimantan, and Irian Jaya, and tropical forests generally have higher rates of litter production than temperate forests (Bray and Gorham 1964). Mangrove forests in Indonesia are floristically rich with at least 94 species represented (Sukardjo 1994), and produce large quantities of litterfall e.g., in East Kalimantan estimated to be about 21.10 to 29.35 dry weight $\mathrm{t} / \mathrm{ha}$ /year (Sukardjo 1995). They produce a large amount of fixed carbon which is used by man for timber, firewood and charcoal. It is hypothesized that this carbon may also support detritus-based food webs both in the swamp and in surrounding coastal waters. In a global context, mangrove swamps have been recognized as extremely productive ecosystems, which not only have a high rate of primary productivity, but also export organic matter and support a variety of aquatic organisms (Odum and Heald 1972); and most of the aquatic organisms are valuable economically for man. It is generally supposed that mangroves play an important role in supporting a wide range of marine life in near-shore waters and in sustaining coastal fisheries. These highly productive mangrove forests provide critical habitat and food for many organisms, including important fisheries species. However, human population concentrates in the coastal zones, imposing enormous pressure on these mangrove forests. In Indonesia moreover, mangrove swamp communities or mangals (After Macnae 1968) occupy warm coastal areas where land is becoming increasingly valuable for farming, mariculture, and recreation. Thus men's use of mangrove areas in Indonesia for the establishment of ponds for the culture offish and prawns, and other fishery activities, and for timber etc., is practically common.

In Indonesia, mangrove ecosystems or mangroves are found in tidal wetlands under varying conditions of salinity, water-logging, anaerobic substrate, often hyper-saline (>33 \%) and acidic. Many of the largest mangrove areas of Indonesia occupy a significant portion of the deltas of rivers, large and small. Here, mangrove ecosystems are delicate and complex, intensely dynamic and fragile; and their principal components are the physical and chemical environments, the biotic elements (flora and fauna), and human interferences. Each component of the 
environment namely, climate, salinity, freshwater supply, siltation, erosion, substrate and nutrients, act on flora and fauna, and, in-turn, these influence the environment. For instance, reduced freshwater flow through a mangrove forest probably not only reduces the nutrient input from surrounding terrestrial areas, but also results in higher soil salinities. Thus, it becomes a stress for mangroves itself and their associated meiofauna.

Mangrove ecosystems are open systems and the cycles of material transport in mangrove forests are driven by physical and biological factors that control the rate of input and output of inorganic and organic components. Changes in the quality of water entering and leaving the mangroves are particularly important in determining natural cycles. In addition, they support a characteristic fauna which includes crabs, shrimps and molluscs. The waterways support a varied fauna of fish, shrimp and plankters. The general acceptance is prawn fisheries are important commercial fisheries in many developing countries and developed countries.

\section{AN ECOLOGICAL IMPORTANCE OF THE MANGROVE ECOSYSTEM - Fishery Aspects}

\section{Ecological Features of Mangroves as Fish Habitat}

Mangrove forests are a common type of pan-tropical coastal vegetation. In Indonesia, characteristics of mangrove sites varied provincially and locally, but it does have the same serve as fish habitats and refuges for a large number of species of conservation concern. For instance, in the estuary of the Rokan River in Sumatra, Hardenberg (1950) has reported the occurrence of some 175 species, including occasional migrants. The number of individuals is, however, high. In Indonesia, there are large marine mangal areas in an environment characterized by tidal ranges of 2-5 m, fluctuating salinities of 28-33\%o, high atmospheric humidity and constant subequatorial temperatures; and mangrove forests of embankments, lagoons, and harbors are less dominated by hydrological factors. For instance, the coast of Java experiences strong semi-diurnal tides, with a range of $5 \mathrm{~m}$ and above during extreme spring tide. The coast may be classified as a high mesotidal environment. The waters are well mixed vertically, and salinities range from 20 to 32 $\%$. Major dilution occurs from the discharge of freshwater by 11 rivers. Also, wind blowing over the sea surface can cause the disturbance of hydrodynamic sea stability. This condition, furthermore, will result in a rising of sea water towards the surface from the below regions and oceanographically known as upwelling; and it is very beneficial for fishery. In Sumatra and Java, the color of estuarine water may be tea-brown or blackish, due to outflow from enormous peat forests (Hardenberg 1950). The $\mathrm{pH}$ of this water is reported to be as low as 5 or less. There is a marked increase in the number of planktonic organisms as a result of increase in nutrient salts. Copepods diminish to be replaced by an increased amount of diatoms and Noctiluca. Finally, mangrove ecosystems by their nature include an aquatic element; and 
marine species are replaced by coastal forms. For instance, the position of burrowing animals within the substrate is most closely linked to the state of the tide. This may be merely the temporary intrusion of seawater along open coasts at high tide, or it may be the waters of tidal creeks or estuaries surrounded by mangroves. Thus, the unique association of animals and plants, for instance, that dwell upon the roots of mangroves in Indonesian seas are interesting and has long been attracting the attention of naturalists and ecologists.

The structural-functional diversity of the true-mangrove species complex is probably best expressed in the remarkably high diversity of animals for which the ecosystem provides a variety of physical habitats and food sources. For example, the Rhizophora mangroves that predominate the fringe habitat have a well-developed prop-root system that is flooded semi-diurnally by tides and may provide habitat to fishes. Also, some structurally heterogeneous habitats in tidal waters have been shown to provide fish with protection from predators and enhanced feeding opportunities (Rozas and Odum 1988) as can be learned that a large proportion of fish found in mangroves are considered juveniles and species of a small size at maturity (Bell et al. 1984). Thus, the mangroves-fisheries connection may, therefore, lie in the nursery function through provision of food and shelter from predation (Hatcher et al. 1989); and protection from predation is offered by physical structure (e.g., mangrove roots, substratum, and turbidity), in combination with for example, shrimp behavior such as hiding and burying (Dall et al. 1990). Moreover, the estuaries of the Indonesian coastal zone support a varied fish fauna, but it is rather poor in species. The fish fauna consists of species that spend all or a major part of their life in the estuaries, and marine or freshwater species which migrate seasonally into or through the estuaries (Table 1). Consequently, the fish or ichthyoids fauna occurring in and/or within mangroves and/or mangrove environment, have been placed in various ecological groups: as permanent residents, temporary residents or rare species.

Table 1. Types of fish species recorded from Apar mangrove bay areas, East Kalimantan, and from Banyuasin mangrove estuary areas, South Sumatra .

\begin{tabular}{lcccc}
\hline \multicolumn{1}{c}{ Type } & Estuarine Species & Marine Species & Riverine Species & Total *) \\
\hline Adults & 73 & 69 & 25 & 145 \\
Juveniles**) & 45 & 31 & 15 & 68 \\
Total & 73 & 75 & 26 & 151 \\
\hline
\end{tabular}

Notes : * As some species can be classified under several headings, totals given arc not the sums of Columns.

** As the specific identification of juvenile fish is frequently difficult the numbers of species given mere approximations. 
The mangrove forest and aquatic ecosystems are independent, with biological production processes different from those of purely terrestrial forest ecosystems. Due to their characteristic location, the mangroves play an important role in the ecology of the coastal zone area and in support of the marine species that utilizes the mangrove environment during part or all of their life cycles. For instance, some prawn species may breed and complete their life cycle in shallow coastal mangrove waters. Many species require the more saline deep offshore waters to spawn. The larvae then migrate back to the food rich and protective coastal mangrove waters to mature. Adults of the commercially important penaeid prawns usually spawn at sea and after a short larval life (2 to 3 weeks), the post-larval stage settles in the near inshore areas and estuaries (Dall et al. 1990).

Roles of the mangrove forests in interactions with neighboring coastal and marine ecosystems in Indonesia are summarized in Table 2. There are features in common, including physical, chemical characters and effects of seasonality, of the mangrove areas as habitats for fish and other aquatic animals. For certain species of fishes, areas of higher salinities may provide suitable habitat for developing juvenile fishes. Also, the fish of muddy estuaries show affinities to deep-sea fauna in some of their features. Some genera of clupeids and polynemids have prolonged fin-rays, and others have small-diminutive eyes. Hardenberg (1950) has recorded even a species of blind sole from the Rokan estuary. The organic nitrogen compounds of the falling leaves of mangroves are either incorporated into the sediment or converted into peat for detritus - feeding shellfish, or broken up to become food for bacteria, fungi and finfish. The importance of bacteria both as a food source in marine and estuarine sediments and as mineralizing agents has been widely commented upon. Thus exported detritus also provides an important habitat for juvenile prawns in near-shore sub-tidal mudflats (Daniel and Robertson 1990). Johannes (1978) pointed out that many fish in tropical marine environments move inshore to spawn. In this context, he mentioned the Gerridae, Sparidae, Engraulidae, Pomadasydae and Sciaenidae, all of which are demersal coastal forms and spawn in estuaries. For example, in the Palau $\left(8^{\circ} \mathrm{N}, 135^{\circ} \mathrm{E}\right)$ spawning migrations, only Herklotsichthys sp. migrated from its usual seagrass and/or lagoon habitat to spawn in mangrove creeks (Johannes 1978). One common mangrove-deniser, Lutjanus argentimaculatus, migrated to the lagoon and reef slope to spawn. Lethrinus sp and Siganus lineatus were the only other fish which occasionally inhabit mangroves that migrated to spawn on reef slopes.

Estuaries play a role in energy transfer between a river and the sea, which is especially important for many commercial coastal fishes whose fish larvae and juveniles are dependent on the estuary as a nursery and feeding grounds. As discussed by Hambrey (1996a, b), the nursery function of mangrove ecosystem is likely to be highly variable, with some areas being of far greater value, and others of far lower value than the global estimates would suggest. For example, mangrove swamps of reef flats are generally important as nurseries for mullet (Mugilidae) and baitfish (Clupeidae and others), and, together with inland mangroves, are a source of crab (for instance Scylla serrata and Sesarma spp.). The dominant mullet in all 
mangrove creeks is Liza subviridis. Large mullet, Valamugil sp and L. argentea appear to be more abundant in the open main channels of Indonesian mangrove system. Ambassis gymnocephalus is the dominant zoo-planktivore in mangrove creeks. Thus, mangroves are often considered to be important to coastal fisheries both in terms of their role as breeding and nursery grounds for various fish and prawn species, and as a source of food.

Table 2. Roles of the mangrove forest in Indonesia: an experience with the mangrove forests in South China Sea, East Kalimantan, South Sumatra and Segara Anakan Cilacap.

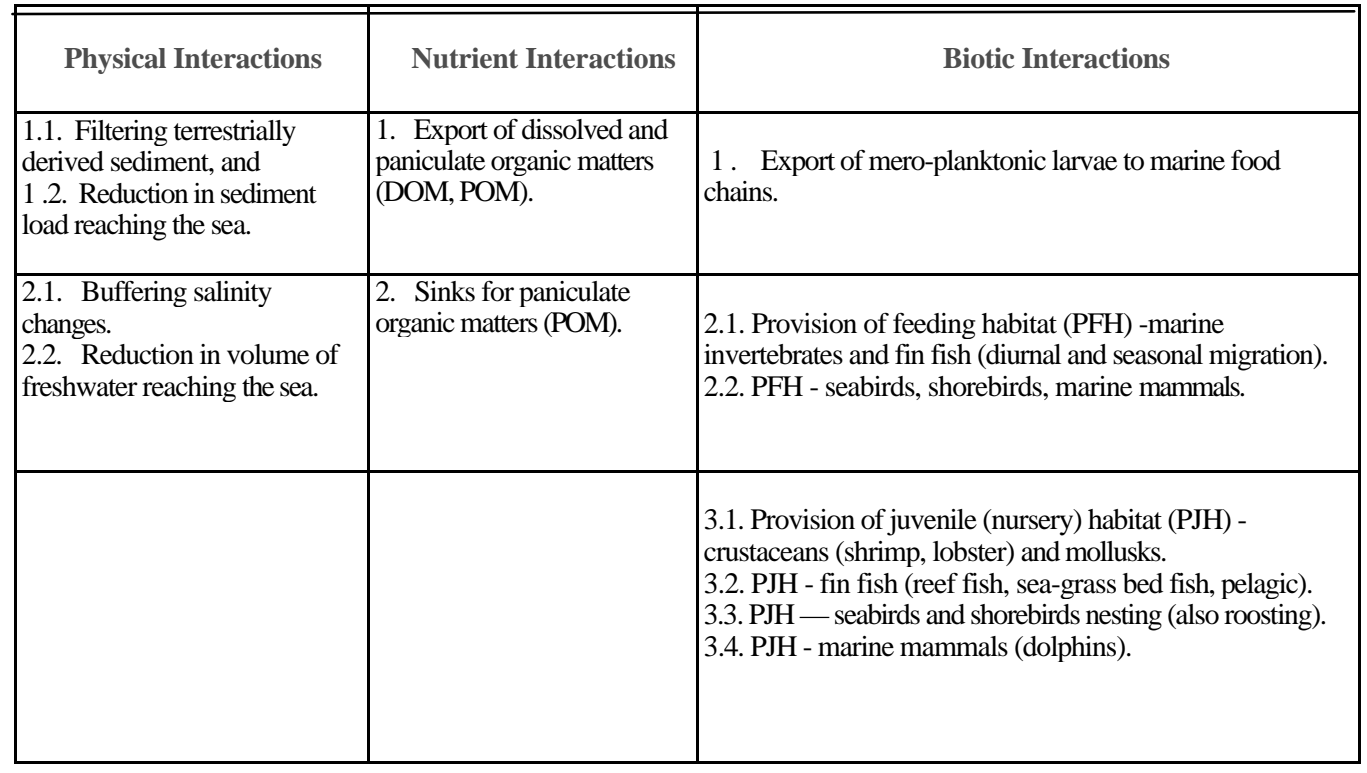

\section{Aquatic Ecology}

The ecological importance of mangrove forests (e.g., Thayer et al. 1987; Robertson and Duke 1987; 1990) in estuarine and coastal ecosystems throughout the world is well established. Estuaries in Indonesia contain diverse habitats, including mangrove forests, sea-grass beds, mudflats and open water channels, all of which may differ in depth, structural heterogeneity, substratum type and tidal exposure.

It is widely accepted that mangrove communities are important components of estuarine ecosystems (Odum 1961; Odum and de la Cruz 1967). Elsewhere in Indonesia, mangroves are associated with estuaries; and most estuaries in Indonesia are mangrove-lined for much of their lengths. Thus, mangrove forests contribute a great amount of structural heterogeneity to these estuaries. Mangroves in the estuaries are able to absorb inorganic compounds from fresh water runoff for photosynthesis and thus play an important role as primary producers. Mangroves are 
a source of primary productivity for food webs that serve as a base for the production of marine and estuarine organisms such as lobsters, finfish and shellfish. Mangrove estuaries and creeks usually have significant salinity fluctuations. The great changes in salinity occurring during rainy seasons may cause periodic mass mortality of marine organisms. On the other hand, changes in salinity will also result in soil salinity of root zones in the mangrove forests.

The mangrove forests and/or association in Indonesia may be considered of great importance too, for example, the South China sea, including the estuaries, adjacent coastal waters and the offshore waters, as its high productivity probably makes it the major source of organic matter. These communities act as nurseries for many organisms and produce large quantities of organic matter (e.g., litter-fall) which forms the base of estuarine food chains. Moreover, their detritus and nutrients are exported out of the ecosystem through tidal flushing and these form a food base for marine micro-organisms which in turn support the valuable estuarine and near-shore fisheries.

The vast mangrove system in Indonesia may be considered as very important in terms of high productivity and as a major source of nutrients to the ecosystem of the estuaries, the adjacent waters and the offshore waters. In Apar Bay East Kalimantan, Sukardjo (1995) found that the total flux of organic matters (woody detritus and other mangrove litter components) estimated to be about 21.11 to 29.34 dry weight $\mathrm{t} / \mathrm{ha}$ /year. This is exported to adjacent waters in the form of fine suspended materials. In Florida, Ray (1974) found that $90 \%$ of water-borne debris within the mangrove zone is derived from mangrove vegetation. About half of this is exported to adjacent waters in the form of fine suspended material so that about $35-60 \%$ of all suspended matter on the off-shore olithic banks is of mangrove origin.

The waters in the deltas, as well as those inshore, carry a large amount of suspended, as well as large plant materials, such as leaves, branches and trunks. Teredinid mollusks play an important role in many mangrove swamps by rapidly breaking down wood and releasing nutrients into the food chain. Since teredinids use wood as a substratum for burrowing and, in many species, as food (Turner 1966, Rayner 1977), the numbers of teredinids may be directly related to the amount of wood available. On the other hand, the major food of sesarmid crabs in mangrove forests is leaf litter (e.g., Malley 1978). These crabs carry leaves down their burrows as well as consuming them on the sediment surface, and Macnae (1968) suggested that feeding by sesarmid crabs may account for the scarcity of leaves on the floors of mangrove forests. It is interesting than that in inland mangroves most of the detritus must be broken down in situ. The high productivity of associated estuaries and banks is due to such suspended matter. In Indonesia, my field observations have shown that fish in the mangrove environment utilize virtually all sources of food available, as follows :

1. Insects and fruits from mangroves and from terrestrial sources (e.g., Toxotes and some catfish). 
2. Detrital mud (e.g., Scatophagus, mullets, some catfish).

3. Small invertebrates (e.g., gudgeons, gobies, ambassids, anchovies, etc.).

4. Prawns and crabs (e.g., Polydactylus, Johnius, Pristia, Lates calcarifer, Kurtus, Scutengraulis, some catfish).

5. Mollusc (e.g., Cinetodus,Acanthopagrus, Tokifugu).

6. Fish (e.g., Carcharhinus, Lates, Johnius, Polydactylus, some catfish).

Some fish are primarily estuarine, with the major portions of their population residing in the mangrove areas. Others appear to enter the estuaries from either the sea or rivers mainly to forage, while others again pass through the area on breeding migrations or breed within the area or in adjacent coastal waters. Those forms which breed within the mangrove belt or in the adjacent sea frequently utilize the area as nursery grounds for juveniles during various stages of development. Marine and riverine forms penetrate the mangrove zones to varying degrees either as small peripheral populations or occasional individual stragglers. Table 2 summarizes the data available in the reports. It gives some idea of the inter-linking of the mangrove community with the adjacent marine and riverine communities and the presence of juveniles indicates which species utilize the mangrove area for breeding or nursery grounds. Thus, the productivity of the mangrove ecosystem is not measured simply by the productivity of plant material by mangroves, but must include the production of fisheries that are dependent on the mangrove detritus.

\section{Ecological Productivity of Mangroves as Habitat and Fisheries}

In Indonesia, mangroves represent the dominant soft bottom plant communities of the marineterrestrial transition in the coastal zone; and considered to be areas of high primary productivity which support economically important detrital-based marine food webs. As a consequence of the range of spatial and temporal variation in physical and chemical factors found in such environments, the biological communities display remarkable adaptations which permit them to survive under such harsh environmental condition. For instance, the extreme ranges of $\mathrm{pH}, \mathrm{DO}$, temperature and salinity are caused by freshwater influx or conversely, by the shallowness of mangrove waters and high incident radiations are common features.

The plant species are members of terrestrial families which have adaptations to survive under conditions of high salinity, low oxygen and nutrient availability in the soil, wind and wave action, and substrate instability. The animals are, like the plants, representatives of largely terrestrial groups. In contrast the aquatic animal community is dominated by members of essentially marine families which are adapted to viable salinity, turbid conditions and to feeding directly or indirectly on materials from the dominant primary producers.

In a global context, mangroves are one of the more productive ecosystems in the world in terms of both primary productivity and the productivity of marine animals. The primary productivity is manifested in terms of the accumulation of 
biomass (wood, root etc.) and the production of leaves. In Indonesia, Sukardjo < Yamada (1992) reported that the biomass of $R$. mucronata amounted to be 93.73 dry weight/ha and mangroves produce a large quantity of organic debris in the fo of leaf litter, viz 7.56-10.82 dry ton/ha/year (Sukardjo 1995). Generally, the tc biomass, height, litterfall, decomposition, and fresh water turnover increase fn dwarf to riverine mangrove forests (Pool et al. 1975, 1977; Brown and Lugo 198 The significance of this detritus in the food web has been recently focused upon some workers (Leh and Sasekumar 1980; Thong and Sasekumar 1980). Mullet a some juvenile fishes, and penaeid shrimps utilize this material in mangrove estuar almost exclusively. Leaves which are continually being shed by mangroves under decomposition and result in POM (Particulate Organic Matters) and DO (Dissolved Organic Matters) that enter into the near-shore estuarine or mari environment. The POM, which consists of small particles, is consumed by larval a; juvenile marine organisms that utilize the mangrove habitat as a nursery and feedii ground. The DOM, which consists of a wide range of soluble organic compounds, consumed by filter feeders (e.g., clams, oysters, mussels, etc.) that are common the near-shore environment, and who retain the phyto-nano-and micro-plankton th is vastly composed of primary producers who need DOM to synthesize organ matter. The production of bacterial biomass from DOM is an important step carbon and energy flow through marine environments and potentially serves as tl mechanism by which dilute dissolved organics become available to metazoc trophic levels (Azam et al. 1983). In addition, any organic material that transported seaward is flocculated by the increasing salinity. The flocculated organ matter (FOM) becomes a substrate for benthic feeders and scavengers. Therefor mangroves are known to be very productive in terms of primary organic mated! and recycling of mineral nutrient (Lugo and Snedaker 1974). Also, the richness c mangroves in organic materials provides a wide variety of food at different levels $\mathrm{c}$ the food web for organisms that will , in turn, serve as fish food (Beumer 1978 Mugil cephalus and Cyprinodon variegatus are mentioned as such. Also, mud crat Scylla serrata occupies a niche between the primary producers and tertiar producers and is thus, an important organism in the energy-flow of the mangrov ecosystem.

Sukardjo (1995) reported that the canopy closure by mangrove trees range 87.70-99.00\%. Macnae and Kalk (1962) considered that shading by mangrove tree protects animals, particularly juvenile and larval forms, in shallow water (e.g. mangrove creeks) from direct sun. In addition, the complex and entangled mangrovi roots and stems offer refuge and protection from predators. Thus, the importance o mangroves as habitat for fish and prawns continues to be a topic of debate amonj marine ecologists (Macnae 1974; Robertson and Duke 1987). The detritus is eithei refractory and sinks to the bottom, presumably never enters the food chain, or is dispersed over a large area without any local impact (e.g., magnification of benthic secondary production). However, it should note that marine ecologists generall $\}$ agree that inshore areas constitute a crucial part of the life support systems oi offshore populations by providing nursery and feeding areas (Jansson et al. 1988). 
Therefore, biologists have recently paid much attention to the mangrove areas as nursery areas for shrimp and fish, such as certain species of penaeids that are dependent on mangrove forests during their juvenile stages. These species include Penaeus monodon, $P$. indicus, $P$. merguiensis and most species of Metapenaeus, $P$. semisulcatus and $P$. latisulcatus spend larval and juvenile stages. The life cycle of these prawns and environmental factors influencing it, are summarized in Figure 1. It has been shown that the mangroves and the environment they create is vital to the continuation of many commercial penaeid prawn fisheries. Also, many commercially important fishes such as Chanos sp., Mtigil sp., Hilsa sp., and Pomadasys sp. use mangrove water ways as nursery grounds. Moreover, mangrove communities function as a solar-powered, tidal subsidized and pulse stabilized ecosystem (Odum 1974). There is a large energy surplus in mangroves in the form of detritus. The detritus forms the basic component in the marine primary consumers diet, and thus, a basic support for many commercial fisheries. Therefore, the role of mangroves as a habitat for fish and prawn is interesting, even today.

$P$. merguiensis is an important component of the commercial catches of penaeid prawns throughout Indonesia. The population dynamics of juvenile $P$. merguiensis in estuarine systems in Indonesia have been studied intensively by Toro and Sukardjo (1990), and mangrove-lined mud banks have been shown to be the main nursery area for this species. However, until recently, little research had been carried out on the behavior of juvenile $P$. merguiensis or the degree to which they utilize the mangroves. From the inventory of various sources, hundreds species of fish and prawn belonging to residents and non-residents will be found in the mangrove environment in Indonesia (Table 2). But not all non-resident fish found in mangroves inhabit them as fry or juveniles.

In Indonesia, six habitat groups can be identified in the mangrove environment. Not all of the species will be found in any one of the habitat group. Different resident species occupy different habitat in the mangrove ecosystem (Table 3). For instance, in Indonesia generally, the mudflat fish community consisted of mainly Ambassids, Ariids, Clupeids, Cynoglossids, Engraulids, Mugilids and Sciaenids. Five residents species found only on the mudflats were the catshark Hemiscyllium indicum, the grey mullet Liza argentea, the silver pennah croaker Pennalia argentata, the spotted croaker Protonibea diacanthus and the anchovy Stolephorus macroleptus. Also, the mangrove inlets and creeks were dominated by schooling fish species belonging to the families Ambassidae, Eleotridae, Engraulidae, Clupeidae, Leiognathidae and Mugilidae. Among those, the dominant species in terms of weight were Arius sagor, Ambassis gymnocephalus, Liza subviridis, Toxotesjaculator, Sphyraena barracuda and Lates carcarifer. By using gillnet, $70 \%$ of the total catches consisted of Sardinella melanura, Thryssa kammalesis, T. hamiltonii and Stolephorus indicus. Also, several demersal fish species reportedly inhabit the creeks. Thus, only 29 species are recorded to be commonly found in all of the habitat groups (Table 4). 


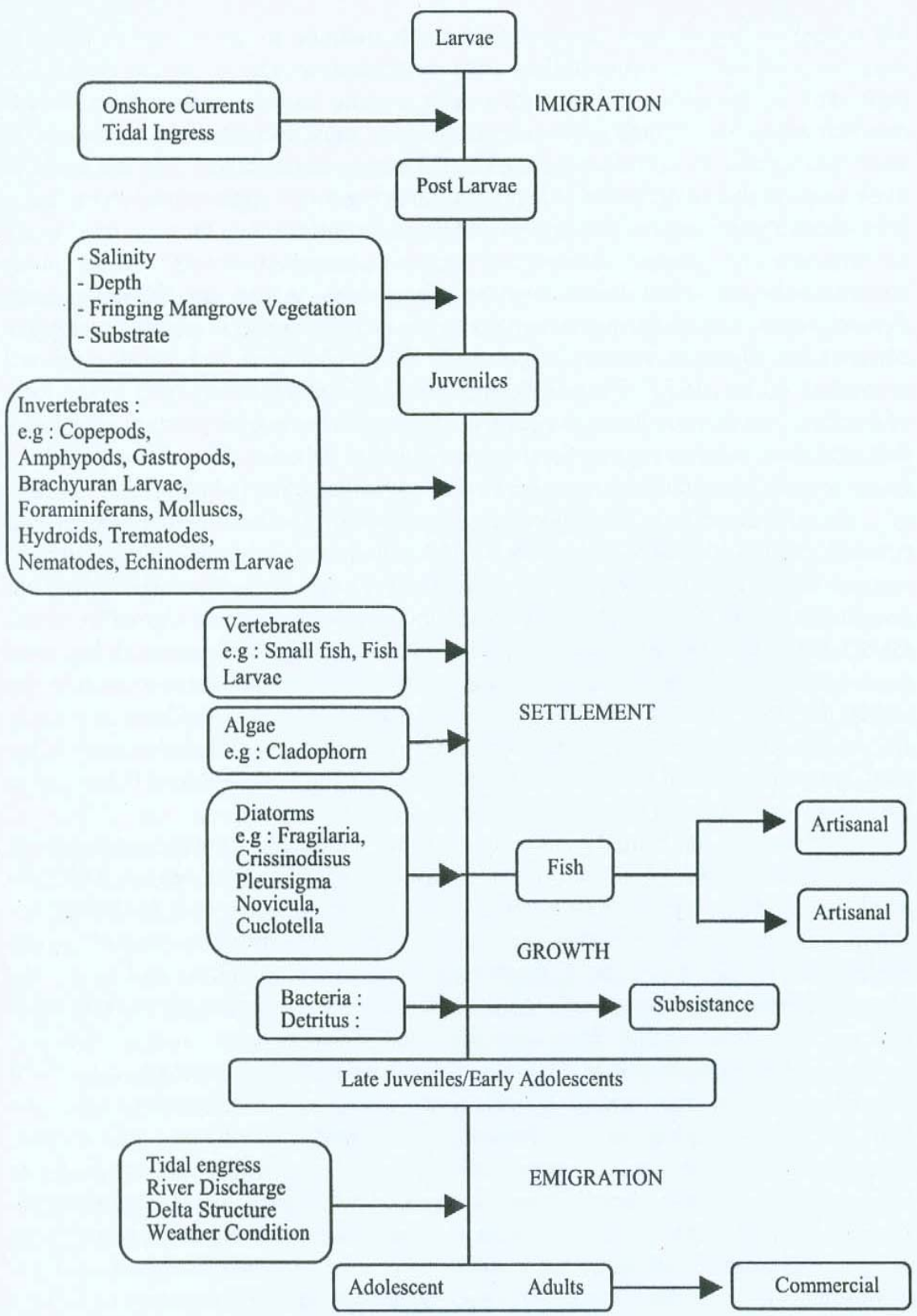

Figure 1. summary of the Factors Afecting Penaeid prawn in the Mangrove Ecosystem 
Fisheries associated with mangrove ecosystem in Indonesia - Sukristijono Sukardjo

Table 3. Resident species of fishes and prawns in the habitat group in the inshore waters of Indonesia (Sources: from various sources).

\begin{tabular}{|c|c|c|c|c|c|}
\hline Species & Family & $\begin{array}{l}\text { Mangrove } \\
\text { creeks \& } \\
\text { inlets }\end{array}$ & Mudflat & $\begin{array}{c}\text { Near } \\
\text { inshore } \\
\text { waters }\end{array}$ & $\begin{array}{c}\text { Far inshore } \\
\text { waters }\end{array}$ \\
\hline 1. Abalites stellaris & Balistidae & - & - & - & + \\
\hline 2. Ablennes hians & Belonnidae & + & - & - & - \\
\hline 3. Acentrogobius caninus & Gobiidae & + & - & - & - \\
\hline 4. Alepes djeddaba & Carangidac & - & - & - & + \\
\hline 5. Ambassis commersonii & Ambassidac & + & - & - & - \\
\hline 6. A. gymnocephalus & Ambassidac & + & - & - & - \\
\hline 7. Amphotistius imbricatus & Dasyatidac & + & - & - & - \\
\hline 8. Anguillia nebulosa & Anguillidae & + & - & - & - \\
\hline 9. Apogon hyalosoma & Apogonidac & + & - & - & - \\
\hline 10. Arothron leopardus & Tetraodontidae & + & - & - & - \\
\hline 11. Atropus atropus & Carangidac & - & - & - & + \\
\hline 12. Bagridac spp. & Bagridac & + & - & - & - \\
\hline 13. Batrachocephalus mino & Ariidac & + & - & - & - \\
\hline 14. Boleopthalmus boddacrti & Gobiidac & + & - & - & - \\
\hline 15. Butis butis & Elcotridac & + & - & - & - \\
\hline 16. Caranx melampygus & Carangidac & + & - & - & - \\
\hline 17. C. sansen & Carangidac & + & - & - & - \\
\hline 18. Carangidae $\mathrm{sp}$ & Carangidac & + & - & - & - \\
\hline 19. Coilia dussumieri & Engraulidac & - & - & - & + \\
\hline 20. Dendroscorpaena sp. & Scorpacnidac & - & - & - & + \\
\hline 21. Elops morchnata & Elopidae & + & - & - & - \\
\hline 22. Ephinephelus fario & Serranidae & + & - & - & - \\
\hline 23. Ephippus orbis & Ephippidac & - & - & - & + \\
\hline 24. Gerres filamentosa & Gerridac & + & - & - & - \\
\hline 25. Johnius aneus & Scianediae & + & - & - & - \\
\hline 26. Laputa cingalensis & Serranidac (?) & - & - & - & + \\
\hline 27. Lates carcarifer & Latidac & + & - & - & - \\
\hline 28. Leiognathus daura & Leiognathidae & + & - & - & - \\
\hline 29. L. lioneclatus & Leiognathidac & + & - & - & - \\
\hline 30. L. splendens & Leiognathidac & + & - & - & - \\
\hline 31. Liza argentea & Mugilidae & - & + & - & - \\
\hline
\end{tabular}


Table 3. (Continued)

\begin{tabular}{|c|c|c|c|c|c|}
\hline Species & Family & $\begin{array}{c}\text { Mangrove } \\
\text { creeks \& } \\
\text { inlets }\end{array}$ & Mudflat & $\begin{array}{l}\text { Near } \\
\text { inshore } \\
\text { waters }\end{array}$ & $\begin{array}{c}\text { Far inshore } \\
\text { waters }\end{array}$ \\
\hline 32. Monodactylus argenteus & Monodactylidae & + & - & - & - \\
\hline 33. Ophiocara paracephala & Eleotridae & + & - & - & - \\
\hline 34. Opisthopterus tardoore & Clupeidae & - & - & - & + \\
\hline $\begin{array}{l}\text { 35. Oesteogeneiosus } \\
\text { sthenocephalus }\end{array}$ & Ariidac & - & - & + & - \\
\hline 36. Otolithoides brunneus & Sciaenidae & - & - & - & + \\
\hline 37. Pannalia argentata & Sciaenidae & - & + & - & - \\
\hline $\begin{array}{l}\text { 38. Periophthalmodon } \\
\text { scholsseri }\end{array}$ & Gobiidac & + & - & - & - \\
\hline 39. Platax teira & Platacidae & - & - & - & + \\
\hline 40. Platycephalus asper & Platycephalidac & - & - & - & + \\
\hline 41. P. indicus & Platycephalidae & + & - & - & - \\
\hline 42. Patamolosa sp & Clupeidae & + & - & - & - \\
\hline 43. Prinobutis koilomatodon & Eleotridae & + & - & - & - \\
\hline 44. Protonibea diacanthus & Elcotridac & - & + & - & - \\
\hline 45. Psettodes erumei & Psettodidac & - & - & + & - \\
\hline 46. Rastrellinger kanargurta & Scambridae & - & - & - & + \\
\hline 47. Sardinella gibbosa & Clupeidae & - & - & + & - \\
\hline 48. S. fimbricata & Clupeidac & - & - & + & - \\
\hline 49. Saurida undosquernis & Synodontiidae & - & - & - & + \\
\hline 50. Seluroides leptolepis & Carangidae & - & - & - & + \\
\hline 51. Secutor ruconius & Leiognathidac & - & - & - & + \\
\hline 52. Siganus vermiculatus & Siganidac & + & - & - & - \\
\hline 53. Sphyracna barracuda & Sphyraenidae & + & - & - & - \\
\hline 54. S. jello & Sphyraenidae & + & - & - & - \\
\hline 55. Stolephorus macroleptus & Engraulidae & - & + & - & - \\
\hline 56. Synoptura commersoniana & Soleidae & - & - & - & + \\
\hline 57. Thryssa mystax & Engraulidac & + & - & - & - \\
\hline 58. T. setirostris & Engraulidae & + & - & - & - \\
\hline 59. Thunnidae & Thunnidac & - & - & - & + \\
\hline 60. Thysanophrys indicus & Platycephalidae & + & - & - & - \\
\hline 61. Tilapia mossambica & Cichlidae & + & - & - & - \\
\hline
\end{tabular}


Table 3. (Continued)

\begin{tabular}{|l|l|c|c|c|c|}
\hline \hline \multicolumn{1}{|c|}{ Species } & \multicolumn{1}{|c|}{ Family } & $\begin{array}{c}\text { Mangrove } \\
\text { creeks \& } \\
\text { inlets }\end{array}$ & Mudflat & $\begin{array}{c}\text { Near } \\
\text { inshore } \\
\text { waters }\end{array}$ & $\begin{array}{c}\text { Far inshore } \\
\text { waters }\end{array}$ \\
\hline 62. Toxotes jaculator & Toxotidac & + & - & - & - \\
\hline 63. Tylosurus leiurus & Belonidac & + & - & - & - \\
\hline 64. Uranoscopus sp. & Uranoscopidac & - & - & - & + \\
\hline 65. Uropterygius concolor & Muraenidae & + & - & - & - \\
\hline 66. Zenarchopterus buffoni & Hemiramphidac & + & - & - & - \\
\hline 67. Z. candorittatus & Hemiramphidac & + & - & - & - \\
\hline 68. Metapenaeus ensis & Penacidac & + & - & - & - \\
\hline 69. M. Lysianassa & Penaeidac & - & + & - & - \\
\hline 70. M. Stridulans & Penacidac & - & - & - & + \\
\hline 71. Palaemon styliferus & Palaemonidac & - & + & - & - \\
\hline 72. Penacus monodon & Penaeidac & + & - & - & - \\
\hline
\end{tabular}

Table 4. Fish and prawn species commonly found in the habitat of mangrove ecosystem (including inshore waters) in Indonesia (Sources: from various sources).

\begin{tabular}{|l|l|c|c|c|c|}
\hline \hline \multicolumn{1}{|c|}{ Species } & \multicolumn{1}{|c|}{ Family } & $\begin{array}{c}\text { Mangrove } \\
\text { creeks \& } \\
\text { inlets }\end{array}$ & Mudflat & $\begin{array}{c}\text { Near } \\
\text { inshore } \\
\text { waters }\end{array}$ & $\begin{array}{c}\text { Far inshore } \\
\text { waters }\end{array}$ \\
\hline $\begin{array}{l}\text { 1. Ambassis gymnoce- } \\
\text { phalus }\end{array}$ & Ambassidac & + & + & + & + \\
\hline 2. Carangoides malabaricus & Carangidae & + & + & + & + \\
\hline 3. Dasyatis zugei & Dasyatidac & + & + & + & + \\
\hline 4. Gastrophysus lunaris & Tetrodontidae & + & + & + & + \\
\hline 5. Gerres abbreviatus & Gerridac & + & + & + & + \\
\hline 6. Gobiidae sp.1 & Gobiidac & + & + & + & + \\
\hline 7. Johnius belangerii & Sciancdiac & + & + & + & + \\
\hline 8. J. coitor & Scianediac & + & + & + & + \\
\hline 9. Leiognatus brevirostris & Leiognathidac & + & + & + & + \\
\hline 10. Liza subviridis & Mugilidac & + & + & + & + \\
\hline 11. Otolithes ruber & Scianediac & + & + & + & + \\
\hline 12. Platycephalus scaber & Platyecephalidac & + & + & + & + \\
\hline 13. Polynemus sextarius & Polynemidac & + & + & + & + \\
\hline
\end{tabular}


Table 4. (Continued)

\begin{tabular}{|l|l|c|c|c|c|}
\hline \multicolumn{1}{|c|}{ Species } & \multicolumn{1}{|c|}{ Family } & $\begin{array}{c}\text { Mangrove } \\
\text { creeks } \\
\text { inlets }\end{array}$ & Mudflat & $\begin{array}{c}\text { Near } \\
\text { inshore } \\
\text { waters }\end{array}$ & $\begin{array}{c}\text { Far inshore } \\
\text { waters }\end{array}$ \\
\hline 14. Saurida tumbil & Synodontiidae & + & + & + & + \\
\hline 15. Sccutor insidiator & Leiognathidac & + & + & + & + \\
\hline 16. Sctipinna taty & Clupcidae & + & + & + & + \\
\hline 17. Sillago sihama & Sillaginidac & + & + & + & + \\
\hline $\begin{array}{l}\text { 18. Stigmatogobius } \\
\text { sadanundio }\end{array}$ & Gobiidac & + & + & + & + \\
\hline 19. Stolcphorus tri & Engraulidae & + & + & + & + \\
\hline 20. Tcnulosa sinensis & Clupeidac & + & + & + & + \\
\hline 21. Thcrapon jarbua & Theraponidae & + & + & + & + \\
\hline 22. Thryssa hamiltonii & Engraulidae & + & + & + & + \\
\hline 23. T. kammalcnsis & Engraulidae & + & + & + & + \\
\hline 24. Trichiurus savala & Trichiuridac & + & + & + & + \\
\hline 25. Trypauchcn vagina & Gobiidae & + & + & + & + \\
\hline 26. Mctapenacus affinis & Penaeidac & + & + & + \\
\hline 27. M. brevicornis & Pcnacidae & + & + & + \\
\hline 28. Parapcnacopsis sculptilis & Penaeidac & Penaeidac & + & + & + \\
\hline 29. Pcnacus merguiensis & & + & + & + \\
\hline
\end{tabular}

\section{DISCUSSIONS AND CONCLUDING REMARKS: An Indonesian Perspective}

A positive correlation between near-shore catches of shrimp or fish and mangrove area has been documented for Indonesia (Martosubroto and Naamin 1977), Malaysia (Gedney et al. 1982), Australia (Staples et al. 1985), the Philippines (Camacho and Bagarinoa 1987) and elsewhere (cf. Table 5). Also, there exists an obvious link between the fishery in the immature mangrove system and the one in the adjacent marine system. Fish populations in both estuaries and mangrove ecosystems can be abundant with a wide diversity of species. It is well known to fishermen that many species of fishes occur in mangrove estuaries and creeks, and it has been observed many times that these systems act as nursery areas for larval and juvenile fishes. A comprehensive listing of fish species that actually spend their juvenile years in mangrove environments has yet to be made. Nor is it known to what degree the relationship is obligate or facultative for particular species. Much of the evidence is circumstantial. Moreover, the structural heterogeneity of habitats in tidal waters has been shown to provide fish with protection from predators and 
Fisheries associated with mangrove ecosystem in Indonesia - Sukristijono Sukardjo

Table 5. Quantified relationships between mangroves and coastal resources.

\begin{tabular}{|c|c|c|c|c|}
\hline No. & Study Site & Formula & References & Remarks \\
\hline 1. & Indonesia & $\begin{array}{l}Y=0.1128 X+5.473 \\
\left(r^{2}=0.79, n=N A\right)\end{array}$ & $\begin{array}{l}\text { Martosubroto and } \\
\text { Naamin } 1977\end{array}$ & $\begin{array}{l}\mathrm{Y}=\text { Shrimp production } \\
\text { (x } 1000 \text { tons) } \\
\mathrm{X}=\text { Mangrove area } \\
\text { (x 10,000 ha) }\end{array}$ \\
\hline 2 , & Philippines & $\begin{array}{l}Y=0,8648 X+0.0991 \\
\left(1^{\wedge}=0.66^{\wedge}=17\right)\end{array}$ & $\begin{array}{l}\text { Paw and Chua } \\
1989\end{array}$ & $\begin{array}{l}\mathrm{Y}=\mathrm{Log} 10 \text { of penacid } \\
\text { shrimp catch (tons) } \\
\mathrm{X}=\log 10 \text { of mangrove } \\
\text { area }\end{array}$ \\
\hline 3. & $\begin{array}{l}38 \text { regions of } \\
\text { the world }\end{array}$ & $\begin{array}{l}\text { Log } 10 M S Y=0.4875 \\
\log A M-0.0212 L+2.41\end{array}$ & $\begin{array}{l}\text { Pauly and Ingles } \\
1986\end{array}$ & $\begin{array}{l}\text { MSY = Maximum } \\
\text { Sustainablc Yield of } \\
\text { pcnacids } \\
\text { AM = Area of mangroves } \\
\text { L = Degrees of latitude }\end{array}$ \\
\hline 4. & Australia & $\begin{array}{l}Y=1.074 X+218.3 \\
\left(r^{2}=0.58, n=6\right)\end{array}$ & Staples et al. 1985 & $\begin{array}{l}Y=\text { Banana prawn catch } \\
\text { (tons) } \\
X=\text { Mangrove shoreline } \\
(\mathrm{Km})\end{array}$ \\
\hline 5. & $\begin{array}{l}\text { NortheastGulf } \\
\text { of Mexico and } \\
\text { in Lousiana }\end{array}$ & $\begin{array}{l}Y=1.96 X-4.39 \\
\left(r^{2}=0.92, n=7\right)\end{array}$ & Tumer 1977 & $\begin{array}{l}\mathrm{Y}=\text { Percentage of brown } \\
\text { shrimps } \\
\mathrm{X}=\% \text { of saline vegetation } \\
\text { in an hydrological unit }\end{array}$ \\
\hline 6. & $\begin{array}{l}27 \text { locations in } \\
\text { Asia, America } \\
\text { and Africa }\end{array}$ & $\begin{array}{l}\text { No equation given } \\
\left(\mathrm{r}^{2}=0.69, \mathrm{n}=5 ; 8\right)\end{array}$ & In: Turner 1977 & $\begin{array}{l}\mathrm{Y}=\text { Annual shrimp yield } \\
\mathrm{X}=\text { Hectare of vegetated } \\
\text { estuary }\end{array}$ \\
\hline 7. & Gulf of Mexico & $\begin{array}{l}\operatorname{Ln} Y=0.496 \operatorname{Ln} X+6.070 \\
\left(r^{2}=0.48, n=10\right)\end{array}$ & $\begin{array}{l}\text { Yancz-Arancibia et } \\
\text { al. } 1985\end{array}$ & $\begin{array}{l}\mathrm{Y}=\text { Fish capture (tons) } \\
\mathrm{X}=\text { Coastal marshes in } \mathrm{km}^{2}\end{array}$ \\
\hline
\end{tabular}

enhanced feeding opportunities (Rozas and Odum 1988). Indeed, the supposed connection between mangroves and juvenile nekton is often advanced as one of the key arguments for the conservation of mangrove forests in Indonesia. Unfortunately, the use of fringing mangrove habitats by commercial and recreational fishery in Indonesia has not been well documented. Also, no reliable catch statistics are available for both commercial and recreational fish production from mangroves. Moreover, in Indonesia, very little and/or no listing is made of various teleost families, such as the Apogonidae, Bothidae, Chandidae, Chanidae, Dorosomidae, Elopidae, Engraulidae, Gerridae, Latidae, Leiognathidae, Megalopidae, Platy-cephalidae, Pseudomugilidae, Soleidae, Syngnathidae and Toxotidae, all of which 
contain species occurring in mangrove systems. While the ichthyo fauna occurring within mangrove environment may be broadly categorized into those fishes that exist there permanently, those that intermittently enter them as adults, and those that seasonally occur there as eggs, larvae, or juveniles. Thus, one of the principal reasons for rehabilitating mangrove ecosystem in Indonesia is to increase biodiversity and conserve the ecosystem.

Mangroves are often considered as an ecosystem per se, due to their strong specificities (Twilley et al. 1996) but they belong to intermittently brackish tidal zone and can be seen as a part of estuarine systems. Young fish utilize estuaries, near shores marine areas and mangrove ecosystem in order to benefit from the availability of food and perhaps also to gain protection from predators. In Indonesia, estuaries can be considered ecosystems because they are composed of numerous subsystems or habitats. The term habitat refers to the place occupied by an entire community of organisms. Thus estuaries are known to be important as feeding, nursery, or habitat areas, in the life cycles of many fish species, while the role of estuaries, particularly mangrove, in producing commercially important fishes is being recognized, their value for fishes of little or indirect commercial or angling importance has not been accepted. It seems that estuaries, all over the world are mainly nursery for many marine animals. As a matter of fact, the problem of exact relationship existing between ichthyology and mangroves is far from being solved. Even in temperate estuaries there are groups of important fishes which spend a part of their life either in the estuary itself or in the ocean during their life cycles.

In recent years, the importance of the mangroves is well established (e.g., critical feeding, rearing and nursery habitat for economically important marine species, providing a buffer against storms, filtering pollutants from upstream sources, and preventing coastal erosion). Also, quantitative relationships between fish yield and area of mangrove have been well established. For instance, according to Turner (1977) who has analyzed the data for 27 locations in America, Asia and Africa, the abundance of penaeid shrimp is directly related to the absolute area and type of estuarine vegetation. However, in Indonesia, the degree of importance to commercial ecological functions of the mangroves are often under pressure from economic uses of this coastal area. For instance, conversion of mangrove forest which destroys the natural nursery grounds of fish and shellfish aggravated by the conversion of inland freshwater swamp forests which diminished the area of freshwater habitat and affects the supply of water and nutrient to the spawning and nursery areas.

Studies in mangrove communities (e.g., Austin 1971; Odum and Heald 1972; Lasserre and Taffort 1977; Janez-Aranbicia et al. 1980; Bell et al. 1984) have generally concluded that the fish fauna has a low species diversity and high proportion of temporary residents occurring mainly as juvenile. There is however, little evidence of fish spawning or breeding inside mangrove areas. Recorded evidence refers only to gobiid fishes (Penridge 1971) including mudskippers (Boleophthalmus, Periophthalmus, Periophthalmodon, Scartelaos). The abundance 
and species composition of fish and crustaceans in mangroves and their adjacent near-shore habitats (sea-grass, sand-flats, mudflats etc.) at several sites in particular islands of Indonesia are necessary to answer the questions regarding mangroves-fishery relationship. For instance, the correlation between offshore prawn catches and area extent of mangroves (Macnae 1974; Turner 1977; Martosubroto and Naamin 1977) has been suggested to be indication of the dependence of juvenile prawns on mangroves rather than of a food chain link (Hatcher et al. 1989). Though prawns offshore did not carry the mangrove carbon signal, it was shown that several species of juveniles prawns collected from a mangrove inlet consumed mangrove -derived carbon (Rodelli et al. 1984). Another example is, the environmental conditions in the estuaries are not conducive to the survival of the first-stage zoea of Scylla serrata and berried females, therefore, migrate to sea to spawn. Thus, program aimed to test the belief that mangroves as major nursery grounds for juvenile's fish and crustaceans are needed.

In Indonesia, since mangrove forests sustain marine life in estuaries and ponds and act as shelter belts against tropical cyclones, the fresh water needs of mangrove forests should be evaluated in water management practices along the coasts. Moreover, the estuarine is one of the common features in the coastal mangrove belts, and represent an important zone for many marine organisms to feeding, breeding, spawning, and other behavior. In addition, it is essential to determine, for a given local fishery, the real dependency of fish resources on estuarine environment by answering the following questions in regard to the relation with fishery, as follows:

1. Is the estuarine zone essential for a given species?

2. Are there alternative areas for its development?

3. Which parameters are critical in its life-history?

4. What are its trophic relationships with other species?

In Indonesia, major fishing grounds are located in the coastal areas in East Sumatra, South and East Kalimantan, and South Irian Jaya where there are extensive virgin mangrove forests (Table 6) (Chong et al. 1990). Fortunately, ecological information for fisheries fauna associated with mangroves in Indonesia is scant. Fisheries resources in the mangrove environment have usually been examined in terms of their economic potential, and thus only the commercial species such as $P$. monodon has received only detailed bioecological study (e.g., Toro and Sukardjo 1990, 1995). The prawn species of creeks were represented by juvenile Penaeus penicillatus, $P$. merguiensis, $P$. indicus, P. monodon, Metapenaeus brevicornis and M. ensis (affinisT). Also, sediment type and organic carbon have been known to influence the distribution of prawns (e.g., William 1958; Branford 1981; Toro and Sukardjo 1997), as do the effects of salinity (e.g., Gunter et al. 1964; Mair 1980 ; Dall 1981) and the presence of coastal vegetation (e.g. Young 1978; de Freitas 1986). i he fluctuations and success of prawn fisheries appears more dependent on the juvenile stage, and the conditions in the mangroves which influence it (e.g., salinity, water discharge, sediment type etc.), than any other part of its life history. 
Thus, the small number of prawn species as observed in mangrove habitats in Indonesia could be due to the following three factors:

1. Niche occupation being limited to the epibenthic surface of the substrate.

2. The substrate being comparatively homogenous (in this case, a largely silt-clay one), and

3. A lack of euryhaline species.

Traditionally mangrove ecosystems have provided some of the richest fishing grounds for much of the islands in the country. Also, fishery activity within the mangroves is mainly at the subsistence level (cf. Table 6). For instance, crabs belonging to different genera and species are abundant along the estuarine shores and mangrove swamps, but those of economic importance affording minor fisheries are the swimming crabs belonging to the genera Scylla and Neptumis. Scylla serrata, Neptunus pelagicus and $N$. sanguinolentus are the most common forms. Therefore, methods and sampling time, and type of nets will catch different species composition by weight and diversity. Fishing gear utilized includes fixed traps (sero and kelong), hook and line, cast nets, gillnets, beach seine, trammel net, stationary lift net and stationary tidal seine (logo), e.g. in Muna (Table 7). The gill nets for instance, were not effective in catching the demersal fish and prawns. Main demersal fish caught are Ariidae, Carangidae (excluding Megalaspis spp. and Decapterus spp.), Leiognathidae, Lutjanidae, Polynemidae, Sciaenidae, Serranidae. Main pelagic fish caught are Rastrellinger spp., Megalaspis cordyla, Decapterus spp., and Sardines (Clupeidae). Multiple tidal nets are usually set up in the main river streams for catching shrimp.Trammel nets are used in river mouths for catching coastal shrimp such as $P$. merguiensis, $P$. monodon and $M$. brevicornis. Traps (sero) are placed at river mouths or at the edge of the mangrove forests. Crab nets are used at the river edge or in small canals and streams for catching mangrove crabs. For instance crab nets are very valuable and efficient economically for fishermen in Muna (Tables 7, 8). Thus, the people who live within the mangrove ecosystems and exploit them have adapted their life-style and landuse patterns in a variety of ways along the Indonesian coasts, e.g., in South Sumatra for general illustration (Table 9).

The results of investigations of fisheries fauna associated with mangroves in Indonesia enable some generalizations to be drawn regarding the structure and composition of mangrove associated fish communities. Such communities appear to be characteristically composed of 13 to 14 families with only 10 families recorded being dominant (Tables 2-4). Some fish families, whose taxonomy is still under review, such as Mugilidae (Thomson, In Lal et al. 1984), Leiognathidae and Lutjanidae (Alien, In Lal et al. 1984) and Sphyrocnidae (Rose, In Lal et al. 1984). FAO (1994) reported that 64 fish species, 74 crustacean species and 71 mollusk species were harvested from the mangrove area in Malay Peninsula.

The main facts that emerged from the discussions on the fisheries associated with mangroves were as follows : 
1. The life cycles, reproduction cycle, food habits and growth rates of mangrove species are poorly known and have only recently been the object of attention in relation to the mangrove ecosystem. The species being investigated are those of economic importance, such as Sesarmids crabs, penaeid prawn, fin fish and certain molluscs.

2. Research on food webs indicates complex pathways, which qualitative measurements of conversion efficiency are available.

3. Migrations, behavior, eco-physiology and habitat requirements of species are partly known but generally poorly understood.

4. Studies on the relationships with adjacent ecosystems such as sea-grass beds and coral reefs are being studied, but only a few are described in any detail.

5. The question was addressed as to what extent forest structure has an effect on fauna populations and trophic relationships, and it was re-emphasized that more studies are urgently needed on this area.

6. The often quoted factors which influence fisheries potential and production in mangrove systems are only described, seldom experimented upon and not quantified.

7. The level of assimilation efficiency has been measured for a few species of animals but measurements are still crude. At this stage we are still looking at quantitative rather than qualitative changes. 
BIOTROPIA NO. 23, 2004

Table 6. Fishery regulations (applied to all of Indonesia): Gear and vessel restriction.

\begin{tabular}{|c|c|c|}
\hline $\begin{array}{c}\text { Zone (Distance from } \\
\text { shoreline) }\end{array}$ & $\begin{array}{c}\text { Vessel size and power } \\
\text { maximum }\end{array}$ & Gear not allowed in zone \\
\hline $1: 0-3$ miles & 5 gross tons, $10 \mathrm{HP}$ & Purse seines, nets $>120$ m length \\
\hline $2: 3-7$ miles & 25 gross tons, $50 \mathrm{HP} 300$ m length \\
\hline $3: 7-12$ miles & 100 gross tons, $200 \mathrm{HP}$ & Nets $>600$ m length \\
\hline $4:>12$ miles & No limit & No limit \\
\hline
\end{tabular}

Table 7. Fishery production in the mangrove forest in Muna project sites in 1996.

\begin{tabular}{|l|c|c|c|c|}
\hline $\begin{array}{c}\text { Fishing gear } \\
\text { (100\% used in the } \\
\text { mangrove area) }\end{array}$ & $\begin{array}{c}\text { Number of fishing } \\
\text { gear (unit) }\end{array}$ & $\begin{array}{c}\text { Number of } \\
\text { fishermen } \\
\text { (H.Hold) }\end{array}$ & $\begin{array}{c}\text { Production } \\
\text { (t/year) }\end{array}$ & Economic value (Rp/year) \\
\hline $\begin{array}{c}\text { 1. Togo (Multiple } \\
\text { Tidal net) }\end{array}$ & 60 & 40 & 87.70 & $500,976,000$ \\
\hline 2. Jala (Cast net) & 8 & 8 & 0.52 & $2,254,000$ \\
\hline 3. Rokkang (Crab net) & 1,300 & 260 & 135.20 & $540,800,000$ \\
\hline
\end{tabular}

Table 8. Fishery product from mangrove forest by species in Muna fish collector in 1996.

\begin{tabular}{|l|c|c|c|}
\hline \multicolumn{1}{|c|}{ Species } & Production (ton/year) & Prize (Rp/kg) & Economic Value (Rp/year) \\
\hline 1. Shrimps & 7.30 & 5,500 & $40,150,000$ \\
\hline 2. Scylla scrrata & 60.00 & 4,500 & $270,000,000$ \\
\hline $\begin{array}{l}\text { 3. Portunus pclagicus } \\
\text { 4. Sea cucumber } \\
\text { (Teripang) }\end{array}$ & 57.36 & 1,000 & $57,360,000$ \\
\hline
\end{tabular}



Fisheries associated with mangrove ecosystem in Indonesia - Sukristijono Sukardjo

Table 9. Coastal zone resource use compatibility matrix: Compatibility of resource use options in South Sumatra (numbers correspond to resource use). $\mathrm{C}=$ Complementary, $\mathrm{H}=$ Harmful, $\mathrm{E}=$ Exclusive

\begin{tabular}{|c|c|c|c|c|c|c|c|c|c|c|c|c|c|c|c|c|c|}
\hline Sector & Item & 1 & 2 & 3 & 4 & 5 & 6 & 7 & 8 & 9 & 10 & 11 & 12 & 13 & 14 & 15 & 16 \\
\hline \multirow{3}{*}{ Fisheries } & 1. Coastal Fishery & * & & & & & & & & & & & & & & & \\
\hline & 2. Inland Fishery & - & $*$ & & & & & & & & & & & & & & \\
\hline & 3. Aquaculturc & $\mathrm{H}$ & $E$ & * & & & & & & & & & & & & & \\
\hline \multirow[t]{6}{*}{ Forestry } & $\begin{array}{l}\text { 4. Large scale } \\
\text { forestry }\end{array}$ & $\mathrm{H}$ & $\mathrm{C}$ & - & * & & & & & & & & & & & & \\
\hline & $\begin{array}{l}\text { 5. Husbandry of } \\
\text { nipa }\end{array}$ & - & - & $\mathrm{H}$ & E & $*$ & & & & & & & & & & & \\
\hline & $\begin{array}{l}\text { 6. Husbandry of } \\
\text { nibung }\end{array}$ & $\mathrm{C}$ & - & $\mathrm{H}$ & $E$ & $\mathrm{C}$ & $*$ & & & & & & & & & & \\
\hline & $\begin{array}{l}\text { 7. Husbandry of } \\
\text { jelutung }\end{array}$ & - & $\mathrm{C}$ & - & $E$ & $\mathrm{C}$ & C & * & & & & & & & & & \\
\hline & $\begin{array}{l}\text { 8. Crocodile } \\
\text { hunting }\end{array}$ & $C$ & $\mathrm{C}$ & $E$ & $E$ & $\mathrm{C}$ & C & $\mathrm{C}$ & $*$ & & & & & & & & \\
\hline & $\begin{array}{l}\text { 9. Monitor lizard } \\
\text { trapping }\end{array}$ & - & - & $\mathrm{H}$ & - & - & - & - & - & & & & & & & & \\
\hline \multirow[t]{2}{*}{ Agriculture } & $\begin{array}{l}\text { 10. Transmigration } \\
\text { scheme }\end{array}$ & $\mathrm{H}$ & & - & E & $\mathrm{H}$ & $\mathrm{H}$ & - & - & $\mathrm{H}$ & * & & & & & & \\
\hline & $\begin{array}{c}\text { 11. Irrigation } \\
\text { scheme }\end{array}$ & - & $\mathrm{E}$ & - & - & - & - & - & - & - & - & $\#$ & & & & & \\
\hline Transport & $\begin{array}{l}\text { 12. Port } \\
\text { construction }\end{array}$ & $\mathrm{H}$ & - & - & - & $\mathrm{H}$ & - & - & - & - & - & - & & & & & \\
\hline Tourism & $\begin{array}{c}\text { 13. Small scale } \\
\text { tourism }\end{array}$ & $\mathrm{C}$ & - & - & - & $\mathrm{C}$ & C & - & - & - & - & - & - & * & & & \\
\hline \multirow[t]{3}{*}{ Conservation } & $\begin{array}{l}\text { 14. Habitat \& } \\
\text { endangered } \\
\text { species }\end{array}$ & $\mathrm{C}$ & $\mathrm{C}$ & $E$ & $E$ & $\mathrm{C}$ & C & - & $\mathrm{H}$ & & $\mathrm{H}$ & $\mathrm{H}$ & $\mathrm{H}$ & C & & & \\
\hline & $\begin{array}{l}\text { 15. Migratory } \\
\text { shore birds }\end{array}$ & $\mathrm{C}$ & C & $E$ & - & $\mathrm{C}$ & $\mathrm{C}$ & - & - & - & $\mathrm{H}$ & $\mathrm{H}$ & $\mathrm{H}$ & C & C & * & \\
\hline & $\begin{array}{l}\text { 16. Breeding water } \\
\text { birds }\end{array}$ & $\mathrm{C}$ & $\mathrm{C}$ & $E$ & - & $\mathrm{C}$ & C & - & - & - & $\mathrm{H}$ & $\mathrm{H}$ & - & C & C & $\mathrm{C}$ & * \\
\hline
\end{tabular}

\section{ACKNOWLEDGMENTS}

The author is very grateful to anonymous reviewers who read critically the manuscript. 
BIOTROPIA NO. 23, 2004

\section{REFERENCES}

Anonim. 2003. Kebijakan dan stratcgi pengelolaan pesisir dan laut (Ocean Policy). Makalah disajikan pada Lokakarya 10 tahun Pengelolaan Lingkungan Pesisir dan Laut di Indonesia: 1993-2003. Jakarta 20-21 Oktober2003.

Austin, M.H. 1971. A survey of the ichthyofauna of the mangroves of western Puerto Rico during December 1967August 1968. Caribbean J. ofSci. 11:427-455.

Azam, F., T. Fenchel, J.G. Field, J.S. Gray, L.A. Meyer-Reil and F. Thingstad. 1983. The ecological role of microbes in the sea. Mar. Ecol. Prog. Ser. 10:257-263.

Becking, J.H., L.G.den Berger and H.W. Mcindcrsma. 1922. Vloed of mangrovcbosschen in Ned-Indie. Tectona 15:561-611.

Bell. J.D., D.A. Pollard, J.J. Burchmore, B.C. Pease and M.J. Middlcton. 1984. Structure of a fish community in a temperate tidal mangrove creek in Botany bay New South Wales. Aust. J. Mar. Fres hwaterRes. 35:33-46.

Beumer, J.P. 1978. Feeding ecology of four fishes from a mangrove creek in north Queensland, Australia. J.Fish.Biol. 12:475-490.

BPS. 1995. Statistik Indonesia. Biro Pusat Statistik, Jakarta. 750p.

Branford, J.R. 1981. Sediment and the distribution of Penaeid shrimp in the Sudanese Red sea. Estuar. Coast. Shelf Sci. 13:349-354.

Bray, J.R and E. Gorham. 1964. Litter production in forests of the world. Adv. Ecol. Research 2:101-157.

Brown, S and A.E. Lugo. 1982. A comparison of structural and functional characteristics of salt water and fresh water forested wetlands. In: Gopal, B., et al. (eds.), Wetland ecology and management, 109-130. International Scientific Jaipur.

Brown, W.H and A.F. Fisher. 1918. Philippines mangrove swamps. Depart, of Agric. \& Natural Res. Bur. of Forestry, Bull.No.17:1-132.

Camacho, A.S and T. Bagarinao. 1987. Impact on fish pond development on the mangrove ecosystem. In: Umali, R.M. (ed.), Mangroves of Asia and the Pacific: Status and management, 383-405. UNDP/UNESCO, Quezon City, Metro Manila.

Chong, V.C., A. Sasekumar, M.U. Leh and R.D. Cruz. 1990. The fish and prawn communities of a Malaysian coastal mangrove system with comparisons to adjacent mudflats and inshore waters. Estuar. Coast. Shelf Sci. 31:703-722.

Dall, W. 1981. Osmoregulatory ability and juvenile habitat preference in some penaeid prawn. J. ofExp. Mar. Biol. \& Ecol. 54:55-64.

Dall, W., B.J. Hill, P.C. Rothlisbcrg and D.J. Staples. 1990. Biology of the Penaeidae. In: Blaxter, J.H and A.J. Southward (eds.), Advance in Marine Biology. Acad. Press. London.

Daniel, P.A and A. I. Robertson. 1990. Epibcnthos of mangrove waterways and open cmbaymcnts community structure and the relationship between exported mangrove detritus and cpifaunal standing stock. Estuar. Coast. Shelf Sci. 31:599-619.

De Frietas, A.J. 1986. Selection of nursery areas by six southeast African Penaeidae. Estuar. Coast. Shelf Sci. 23:901-908.

FAO. 1994. Mangrove forest management guiodelines. FAO Forestry Paper 117, Rome. 319pp. 
Fisheries associated with mangrove ecosystem in Indonesia - Sukristijono Sukardjo

Gcdney, R.H., J.M. Kapctsky and W. Kuhnhold. 1982. Training on assessment of coastal aquaculture potential in Malaysia. SCS/GEN/82/35, Manila.

Gunter, G., J.Y. Christmas and R. Killebrew. 1964. Some relations of salinity to population distributions of mobile cstuarinc organisms with special reference to penaeid shrimp. Ecology 45:181-185.

Hambrey, J. 1996a. Comparative economics of land use options in the mangrove. Aquaculture Asia 1(2):10-14.

Hambrey, J. 1996b. The mangrove questions. Asian Shrimp News, 26, 2nd Quarter 1996. Hardcnbcrg, J.D.F. 1950.

Estuarinc problems in SE. Asia. In: Proc. Indo-Pacif. Fish. Coun.2:175-180.

Hatcher, B., R.E. Johannes and A.I. Robcrtson. 1989. Review of research relevant to the conservation of shallow tropical marine ecosystem. Oceanogr. Mar. Biol. Annu. Rev. 27:337-414.

Jansson, B.O., A.D. Mclntyre, S.W. Nixon, M.M. Pamatmat, B. Zeitzschell and J.J. Zijlstra. 1988. Coastaloffshore interactions - an evaluation of presented evidence. In: Jansson, B.O. (ed.), Coastal-offshore ecosystem interactions, 357-363. Springer - Verlags.

Johannes, R.E. 1978. Reproductive strategics of marine fish in the tropics. Env. Biol. Fishes 3:38-66.

Lal, P., K.Swamy and P. Singh. 1984. Mangrove Ecosystem Fisheries Associated with Mangroves and their Management: Mangrove Fishes in Wairiki Creek and their Implications on the Management of Resources in Fiji. UNESCO Reports in Marine Science No. 27: 93-108. UNESCO Paris. 1984.

Lasscrrc, G and J.L. Toffart. 1977. Echantillonnage et structure dcs populations ichtyologiques dcs mangroves dc Gaudeloupe en September 1975. Cybium 2:115-127.

Leh, C.M.U. and A. Sasckumar. 1980. Fedding ecology of prawns in shallow waters adjoining mangrove shore. In: Soepadmo, E. et al. (eds.), Proc. Asian Symp. On Mangrove Environ.: Res. and Manage., 331-336. Uncsco and Univ. of Malaya.

Lugo, A.E and S.C. Snedakcr. 1974. The ecology of mangroves. Ann. Rev. Ecol. \& Systm. 5:39-64.

Macnac, W. 1968. A general account of the fauna and flora of mangrove swamps and forests in the Indo-West Pacific region. Adv. Mar. Biol. 6:73-270.

Macnac, W. 1974. Mangrove forests and fisheries. FAO Rome. 35p.

Macnac, W and M. Kalk. 1962. The ecology of the mangrove swamps of Inhaca island, Mozambique. J. of Ecology 50:93-128.

Mair, J.McD. 1980. Salinity and water type preferences of four species of postlarval shrimp (Pcnaeus) from West Mexico. J. o/Exp. Mar. Biol \& Ecol. 45:69-82.

Mallcy, D.F. 1878. Degradation of mangrove leaf litter by the tropical scsarmids crab Chiromanthes onychophorum. Mar. Biol. 49(4):377-386.

Martosubroto, P and N. Naamin. 1977. The relationship between tidal forests (mangroves) and commercial shrimp production in Indonesia. Mar. Res. In Indonesia 18:81-86.

Odum, E.P. 1961. The role of tidal marshes in cstuarinc production. The Conservations!, June-July 1961:12-15.

Odum, E.P. 1974. Halophytes, energetic and ecosystems. In: Rcimold, R.J and W.H. Queen (cds.), Ecology of halophytes, 599-602. Acad. Press. NY.

Odum, E.P and A.A. dc la Cruz. 1967. Paniculate detritus in a Georgia salt marsh cstuarine ecosystem. Amer. Ass.Adv. Sci. Pvbl. 83:383-388. 
Odum, W.E and E.J. Heald. 1972. Trophic analysis of an estuarine mangrove community. Bull. Mar. Set. 22:671-738.

Pauly, D and J. Ingles. 1986. The relationship between shrimp yield and intertidal vegetation (mangroves) areas: a reassessment. In: IOC/FAO workshop on recruitment in tropical coastal demersal communities, Ciudad de Carman, Mexico, 21-25 April 1985, 227-284. IOC/UNESCO, Paris.

Paw, J.N and T.E. Chua. 1989. An assessment of the ecological and economic impact of mangrove conversion in Southeast Asia. Mar. Poll. Bull. 20(7):335-343.

Penridge, L.K. 1971. A study of the fish community of a north Queensland mangrove creek. Hons. Thesis 104p. James Cook University, North Queensland.

Pool, D.J., S.C. Snedaker and A.E. Lugo. 1975. Litter production in mangrove forests of southern Florida and Puerto Rico. In: Walsh, G.E., et a!, (cds.), Proc. Int. Symp. Biol. \& Manage. Of Mangroves, 213-237. Inst. Of Food and Agric. Sci., Univ. of Florida, Gainesville.

Pool, D.J., S.C. Snedaker and A.E. Lugo. 1977. Structure of mangrove forests in Florida, Puerto Rico and Costa Rica. Biotropica 9:195-212.

Ray, G.C. 1974. Critical marine habitats. IUCN Publ. New Scr. No.37.IUCN Gland., Switzerland, p. 15-59.

Rayncr, S. 1977. Wood-boring mollusks and crustaceans of mangrove stands. In: Pets, T (ed.), Purari river hydroelectric scheme - environmental studies Vol. 1:30-31. Office of Environment and Conservation, Waegcni and Depart, of Mineral and Energy, Kondolu PNG.

Robertson, A.I and N.C. Duke. 1987. Mangroves as nursery sites: comparison of the abundance and species composition of fish and crustaceans in mangroves and other seashore habitats in tropical Australia. Mar. Biol. 96:193-205.

Robertson, A.I. and N.C. Duke. 1990. Recruitment, growth and residence time of fishes in a tropical Australian mangrove system. Est. Coastal \& Shelf Sci. 31:723-743.

Rollcts, B. 1997. Bibliography on mangrove research: 1600-1975. UNESCO Paris. 479p.

Rodelli, M.R., J.N. Gearing, P.J. Gearing, N. Marshall and A. Sasekumar. 1984. Stable isotope ratio as a tracer of mangrove carbon in Malaysian ecosystems. Oecologia 61:326-333.

Ruitcnbcck, H.J. 1991. Mangrove management: an economic analysis of management options with a focus on Bintuni bay Irian Jaya. Mcntcri Negara Kependudukan dan Lingkungan Hidup Rcpublik Indonesia and EMDI (Unpublished Report). 51 p.

Rozas, P.L and W.E. Odum. 1988. Occupation of submerged aquatic vegetation by fishes: testing the roles of food and refuge. Oecologia (Berlin) 77:101-106.

Schustcr, W.H. 1952. Fish culture in brackish water ponds of Java. Indo-Pac. Fish Comm. Spec. Publ.No. 1:1143.

Staples, D.J., D.J. Vance and D.S. Heales. 1985. Habitat requirements of juvenile penaied prawn and their relationship to offshore fisheries. In: Rothlisberg, P.C., B.J. Hill and D.J. Staples (eds.), Second Aust. Nat. Prawn Seminar Kooralbyn Australia, 47-54.

Sukardjo, S. 1994. Conservation strategy of the mangrove forest in Indonesia: a functional consideration. In: Wells, P.G and P.J. Ricketts (cds), Coastal zone Canada 94: Cooperation in the coastal zone -Conf. Proc. Vol.3:10621095. CZCanada Ass., 1994.

Sukardjo, S. 1995. Structure, littcrfall and net primary production in the mangrove forests in East Kalimatan. In: Box, E.O, et al. (eds.), Vegetation science in forestry, 585-611. Kluwer Acad. Publ., The Netherlands. 
Fisheries associated with mangrove ecosystem in Indonesia - Sukristijono Sukardjo

Sukardjo, S. 1997. Integrated coastal zone management in Indonesia. In: Solomon, W., et al. (cds.), Perspectives on ICZM, 227-232. Springer- Vcrlag Berlin Heidelberg.

Sukardjo, S and I. Yamada. 1992. The management problems and research needs of the mangrove forest in the Cimanuk delta complex, Ujung Indramayu, West Java. Southeast Asian Studies 29(4):468-485.

Thaycr, G.W., D.R. Colby and W.F. Hcttlcr. Jr. 1987. Utilization of red mangrove prop habitat by fishes in South Florida. Mar. Ecol Prog. Series. 35:25-38.

Thong, K..L and A. Sasekumar. 1980. Predation of mangrove fauna by marine fishes. In: Socpadmo, E., et al. (eds.), Proc. Asian Symp. On Mangrove Environ.: Res. And Manage., 378-384. Unesco and Univ. Of Malaya.

Toro, A.V and S. Sukardjo. 1987. Substrate udang windu, Penaeus monodon Fabricius di perairan mangrove Scgara Anakan Cilacap. In: Anantawirya, S and S. Notosudarmo, (cds.), Pros. Scm. Ekol. Tanah dan EkoToksi., 42-61. Pencrbit Univ. Kristcn Satya Waxana, Salatiga.

Toro, A.V. and S. Sukardjo. 1990. The relative condition factor and carapace length-weight relationship of Penaeus monodon Fabricius in the Scgara Anakan mangrove waters, Cilacap. Central Java Indonesia. J. Mar. Biol. Ass. India 32(1-2): 150-153.

Toro, A.V and S. Sukardjo. 1995. Pcngaruh pcrubahan temporal pada komposisi ukuran cstimasi parameter pertumbuhan von Bcrtalanffy Penaeus monodon Fabricius di perairan mangrove Scgara Anakan Cilacap. In: Socmodihardho, S., et al. (cds.), Pros. Seminar V Ekosistcm Mangrove, 199-223. Kontribusi MAB Indonesia No.72, LIPI Jakarta.

Turner, R.E. 1966. A survey and illustrated catalogue of the Tcrcdinidac (Mollusca: Bivalve). Muzcum of Comparative Zoology, Harvard Univ. Cambridge.

Turner, R.E. 1977. Intcrtidal vegetation and commercial yields of penaeid shrimp. Trans. Amer. Fish. Soc. 106:411-416.

Twilley, R.R., S.C. Sncdaker, A. Jancz-Arancibia and E. Medina. 1996. Biodiversity and ecosystem processes in tropical estuaries: perspective of mangrove ecosystem. In: Mooney et al. (eds.), Functional roles of biodiversity - a global perspective, 327-379. John Wilcy \& Sons Ltd.

Watson. J.G. 1928. Mangrove forests of the Malay Peninsula. Malay. For. Rec.6:1-175.

William, A.B. 1958. Substrates as a factors in shrimp distribution. Limnology \& Oceanography 3:283-290.

Yancz-Arancibia, A., F.A. Linares, J.W. Jr. Day. 1980. Fish community structure and function in Tcrminos Lagoon, a tropical estuary in the southern Gulf of Mexico. In: Kennedy, V.S. (cd.), Estuarinc perspectives, 465-485. NY and London: Acad. Press.

Yanez-Arancibia, A., G. Soberon-Chavcz and P. Sanchcz -Gill. 1985. Ecology of control mechanisms of natural fish production in the coastal zone. In: Yancz-Arancibia, A (cd.), Fish community ecology in estuaries and coastal lagoon towards an ecosystem integration, 571-595. UNAM Press, Mexico.

Young, P.C. 1986. Morcton Bay, Queensland: a nursery area for juvenile penaeid prawns. Aust. J. Mar. Freshwater Res. 29:55-75. 